\title{
†BOLLÓK JÁNOS
}

\section{A CARMEN SAECULARE ÉS A LUDI SAECULARES}

A Carmen saeculare nem csak Horatius életmúvében, hanem az egész római költészetben sajátos helyet foglal el: ez ugyanis az egyetlen olyan ránk maradt római kardal, melyet bizonyíthatóan eló is adtak, sôt, azt is pontosan tudjuk, mikor, hol, milyen körülmények között adták elő, ugyanakkor Horatius költeményei között hasonlóképpen egyedülálló abból a szempontból, hogy az összes többi carmennel ellentétben a költő életmúvének ez az egyetlen hivatalos, állami megrendelésre készült darabja. ${ }^{1}$

A megírásához indítékul szolgáló ludi saecularest illetően ókori viszonylatban szintén szokatlanul gazdag információk birtokában vagyunk, mindenekelőtt az 1890ben napvilágra került, úgynevezett „tarentumi felirat” jóvoltából, ${ }^{2}$ mely részletesen megörökítette az ünnepségsorozat egész eseménytörténetét és szertartásrendjét. Ehhez járulnak a különböző irodalmi források, így a Phlegónnál (Kr. u. 2. sz.) és Zósimosnál (Kr. u. 5-6. sz.) hagyományozódott, az ünnep megrendezésére és rituáléjára vonatkozó eloórásokat tartalmazó (pseudo-)Sibyllinum, ${ }^{3}$ továbbá Suetonius Augustus-életrajza (31.), és nem utolsósorban maga a Carmen saeculare, hogy csak a legfontosabbakat említsük. ${ }^{4}$ Ezek a források több vonatkozásban kiegészítik és alá-

${ }^{1}$ A Carmen saeculare-nak - mint a horatiusi életmúnek általában - igen gazdag szakirodalma van: ezek összefoglalását 1.: G. La Bua: L' inno nella letteratura poetica latina. Studi sul mondo antico. é. n. 162. - Suetonius: Vita Horati (ed. Klingner) 20-22. Augustus és Horatius viszonyáról: scripta quidem eius usque adeo probavit mansuraque[ perpetua] opinatus est, ut non modo saeculare carmen componendum $\langle e i\rangle$ iniunxerit, sed et Vindelicam victoriam Tiberii Drusique privignorum suorum 〈illustrandam〉, eumque coegerit propter hoc tribus carminum libris ex longo intervallo quartum addere.

${ }_{2}^{2}$ A feliratot először Th. Mommsen adta ki: CIL VI 32323. Az Augustus alatti Carmen saeculare-ra vonatkozó részek fotokópiáját $R$. Paribeni tette közzé: L'Italia imperiale. 1938. 100.; A ludi saeculares-re vonatkozó források ujabb kiadása: G. B. Pighi: De ludis saecularibus (2. kiad.) 1965. Amsterdam, az Augustus alatti játkokról 5. 7b. szól. Két újabb töredéket közöl a feliratból L. Moretti: Frammenti vecchi e nuovi del Commentario dei Ludi secolari del A. C. 17. Rendiconti della Pontificia Academia Romana di Archeologia (1982-84) 55-56. és 361-379.

${ }^{3}$ A Sibyllinum teljes szövegét Zósimos őrizte meg II.5., azonban Phlegón Makrobioiában (FGrH 257 Fr. 37) is találhatók belőle részletek.

${ }^{4}$ A Res gestae-ben Augustus maga is megemlékezik róla: Pro conlegio XV virorum magister conlegii, collega M. Agrippa ludos saeculares C. Furnio C. Silano consulibus feci. (22.) 
támasztják egymást, s így meglehetôsen árnyalt és pontos képet alkothatunk nem csupán magáról az ünnepségsorozatról, hanem megrendezésének politikai-ideológiai hátteréról és Horatius kardalának az ünnep rendjében elfoglalt helyéról is.

A felirat tanúsága szerint a nagyszabású ünnepségsorozat a Kr. e. 17. május 31rốl június 1-re virradó éjszakán kezdődött, és három napon át tartott, középpontjában három éjszakai és három nappali áldozattal úgy, hogy a három nap mindegyikére esett egy-egy éjszakai és nappali áldozat. Az éjszakai áldozatok sorrendben a Moirák, az Eileithyiák, Magna Mater, a nappaliak Iuppiter Optimus Maximus, Iuno Regina, illetve Apollo és Diana tiszteletére szóltak. Az éjszakaiakat a Mars-mezó Tiberis melletti, Tarentumnak nevezett részén Augustus egyedül, míg a nappaliak közül az elsô kettôt a Capitoliumon, a harmadikat a palatinusi Apollo-templom előtt Agrippával együtt mutatta be. Az áldozatokat sellisterniumok, színházi előadások és cirkuszi játékok egészítették ki - ez utóbbiak még június 3. után is hét napon át folytatódtak. A kardalt, melyet - mint a feliraton olvasható - Q. Horatius Flaccus composuit, a harmadik napon adta elô egy vegyes, fiú- és lánykar, előbb a palatinusi Apollo-templomnál, majd a Capitoliumon.

A tarentumi felirat azért is tanulságos, mert egyértelmúen kiderül belőle, hogy a 17. évi ludi saeculares rituáléja, melyet a kor híres jogásza és egyben Augustus egyik bizalmi embere, Ateius Capito állított össze, ${ }^{5}$ csak részben egyezett meg a ludi saeculares elóképének és előzményének számító, Kr. e. 249. évi ludi Tarentini-éval. Ez utóbbi megrendezésére az elsố pun háború idején került sor, amikor a nép körében félelmet keltő prodigiumok hatására a senatus a Xviri (a quindecemviri elődei) testület révén a Sibylla-könyvekhez fordult tanácsért, s ezek alapján bajok elhárítására vonatkozóan azt az utasítást kapta: ut Diti patri et Proserpinae ludi Tarentini in campo Martio fierent tribus noctibus, et hostiae furvae immolantur, utique ludi centesimo quoque anno fierent. ${ }^{6}$ A 249. és a 17. évi ünnepi játékok tehát csak két vonatkozásban hasonlítottak egymáshoz: mindkettôt a Sibylla-könyveket felügyelố testület utasítására rendezték - ennek feje egyébként 17-ben éppen Augustus volt -, és mindkettő három napon át tartott. Lényeges különbség viszont, hogy 17-ben a három éjszakai áldozat kiegészült három nappalival, az éjszakai áldozatok kapcsán pedig Dis és Proserpina neve még csak szóba sem került, hanem - mint láttuk helyüket a Sorsistennők, a szüló nőket segitő Eileithyiák és Magna Mater foglalta el. A korábbi százados játékok szertartásrendjét részletekbe menóen nem ismerjük, az Augustus alattinak viszont van egy feltúnést keltő vonása, mégpedig az, hogy liturgiájában szembeszökő a hármas számnak és többszöröseinek a dominanciája, és nem csupán az ünnep napjainak számát illetően. Iuppiternek, Iunonak és Terra Maternek egy-egy, tehát $3 \times 1$ áldozati állat jutott, a Moiráknak Augustus 9 nőstény juhot és 9

5 Zósimos 2, 4, 2.

${ }^{6}$ Censorinus: De die natal. 17, 8 (Varro nyomán). Az ünnepre általában: $M$. P. Nilsson: saeculares ludi. RE I. A 2.1691-1720. c. 
nôstény kecskét, az Eileithyiáknak 9 lepényt, 9 kalácsot és 9 cipót áldozott, s hasonlóképpen 9 lepényt, 9 kalácsot és 9 cipót kapott áldozati adományként Apolló és Diana; a Carmen saecularét 27-27 tagú, vagyis $3 \times 9$ fiúból és $3 \times 9$ lányból álló kar adta elő. A ritualénak ezek a számai meghatározó szerepet játszottak a kardal szerkezetének kialakításában: a költemény két, egyenként 9 strófából álló nagyobb egységre különül el, ezek pedig $3 \times 3$-as kisebb egységekre tagolódnak, s ehhez az összesen $2 \times 9=18$ strófához járul egy 19. záróstrófa; strófikus szerkezeti képlete tehát: $(3 \times 3)+(3 \times 3)+1 .^{7}$

A kar tagjai énekük elsô nagyobb egységének elsố triászában Phoebust és Dianát invokálják, arra kérve ôket, hogy adják meg mindazt, amiért ebben a szent idôben (tempore sacro) imádkoznak, majd a Napot ( $\mathrm{Sol}$ ) szólítják meg, azt kívánva neki (vagy tôle), hogy Róma városánál nagyobbat soha ne lásson (1-12.) A második triász teljes egészében Eileithyiának van szentelve: könyörögnek hozzá a nők termékenységéért, beleszőve énekükbe az előző évben hozott Lex Iulia de maritandis ordinibus-nak a népszaporulat szempontjából várhatóan áldásos hatását (13-24.). A harmadik harmad valójában három egystrófás kólonból áll: az elsôben a Parcákhoz fordulnak, hogy az eddigi javakat tetézzék további jókkal (25-28.); a másodikban Tellushoz fohászkodnak a növények és az állatok termékenységéért és jó idójárásért (29-32.), míg a harmadikban visszatérnek az énekük kezdetén invokált két istenalakhoz, Apollóhoz és Dianához (33-36.). A második nagyobb egység első triászában a kar, miután összefoglalta Róma ôstörténetét, jólétet, hatalmat, dicsőséget kér az istenektől Romulus utódai számára (37-48.). A második triászban a sikeres múlt után rátér a még sikeresebb jelenre: Róma világuralmára, a parthusok, az indusok és a szkíták meghódolására, a Fides, Pax, Honos, Virtus, Pudor, Copia - az augustusi propaganda jelszavait megtestesító elvont istenalakok — visszatérésére, majd Róma és általában a birodalom épségének és dicsőségének csorbítatlan fennmaradásáért könyörög (49-60.). A harmadik triászban azután, akárcsak az elsố nagyobb egység elsố harmadában, ismét Apollót és Dianát idézi meg, annak a reménységének adva hangot, hogy kettójük támogatásával az eljövendő saeculum is áldásos lesz Róma számára (61-72.). Ezt követi mintegy ráadásként az elköszönô záróstrófa (73-76.)

A carmen nemcsak szerkezeti felépítését illetően, hanem tartalmi szempontból is mindvégig szoros kapcsolatot mutat az ünnep rituáléjával. Ez a kapcsolat az elsô nagy szerkezeti egységben (1-36.) szinte kézzelfogható, hiszen a 4-8. strófában (13-32.) néven nevezve szerepelnek az éjszakai áldozatok istennói, igaz, az áldozatokétól némileg eltéró sorrendben és a feliratétól eltérô névalakkal (felirat: Moerae — Ilithyiae - Magna Mater; carmen : Ilythia — Parcae — Tellus). A második nagy szerkezeti egységben ez az összefüggés már nem ennyire nyilvánvaló ugyan, de léte-

${ }^{7}$ A költemény szerkezetét illetôen egységes a Horatius-filológia álláspontja: Q. Horatius Flaccus erklärt von A. Kiessling I. besorgt von R. Heinze. (12. kiad.) Dublin-Zürich 1966. 471.; E. Fraenkel: Horace. Oxford 1957. 370—371.; Borzsák I.: Horatius. Ódák és epódoszok. Budapest 1975. 506. 
zik: a 37. sor - Roma si vestrum est opus - vestrum-a ugyanis a perióduson belül nyelvtanilag csak a di-re vonatkozhat (45-46.), és a 49. sor - quaeque vos bobus veneratur albis - que-jéból következôen a vos szintén csak a di-re utalhat vissza, márpedig az ünnepen csupán Iuppitert és Iunót tisztelte meg Augustus és Agrippa ilyen áldozattal, vagyis egyértelmú, hogy a $d i$-n óket, azaz Iuppitert és Iunót kell értenünk. Az éjszakai áldozatok istennőire terjedelemben szinte pontosan ugyananynyi sor jut, mint Iunóra és Iuppiterre. A kardalban azonban nem ók játsszák a legfontosabb szerepet, hanem Apollo és Diana. Ez utóbbiakat invokálja az elsố három strófa, velük zárul az elsố nagy szerkezeti egység, hozzájuk szól a második nagy egység harmadik harmada. A gyúrús kompozíciójú költeménynek tehát ők állnak az elején, a közepén és a végén, s így mintegy közrefogják az ünnep többi istenét és istennójét. ${ }^{8}$

Óhatatlanul fölmerül a kérdés, hogy milyen megfontolások késztették Horatiust jelentőségük ilyen mérvú kiemelésére. Erre a legkézenfekvőbb válasz az lehetne, hogy a kardalt azon a napon adták elő, amikor Augustus és Agrippa nekik mutatott be áldozatot a palatinusi Apollo-templom előtt, s az elsô elôadásra ugyanennek a templomnak az area-ában került sor. Csakhogy a carmen nem volt része a rituálénak, ${ }^{9}$ és nem is sajátosan Apollo és Diana tiszteletére íródott: Horatius kardala egyaránt szól mind a három nap isteneihez és istennőihez, és egészében véve azt a benyomást kelti, hogy elóadását oo is és a rendezốk is az ünnepségsorozat érdemi része ünnepélyes lezárásának szánták.

J. Gagé Apollo-tanulmányának megjelenése után ${ }^{10}$ a Horatius-kutatók körében mondhatni általánosan elfogadottá vált az a nézet, amely szerint Apollo és Diana kitüntett szerepe a költeményben Augustus valláspolitikai törekvéseivel magyarázható és azzal, hogy Horatius ezeket a törekvéseket még az elvárt mértéken túl is igyekezett kiszolgálni. ${ }^{11}$

Tény, hogy Rómában sem azelőtt, sem azután nem tett senki annyit Apollo tekintélyének növeléséért és kultuszának propagálásáért, mint Octavianus Augustus. Ez részint családi hagyományaival, részint a véletlenek összjátékával magyarázható. A Suetoniusnál fennmaradt történet (Aug. 94.), mely szerint Atia a hozzá kígyó alakjában közeledő Apollótól foganta Octavianust, nyilván a Nagy Sándor fogantatástörténetének mintájára kiötlött későbbi találmány, mégsem véletlen azonban, hogy éppen Apollo lépett Ámon helyére: Apollo ugyanis — meglehetősen bonyolult

\footnotetext{
${ }^{8}$ Apollónak és Dianának a kardal többi istenével és istennójével való kapcsolatára 1.: T. Oksala: Religion und Mythologie bei Horaz. Commentationes Humanarum Litterarum 51 (1973). HelsinkiHelsingfors $36-37$.

${ }_{9}^{9}$ Az erról folytatott vitához l. E. Fraenkel: i. m. 379-382.

${ }^{10}$ J. Gagé: Observations sur le Carmen saeculare d'Horace. REL 9 (1931) 290-308. = Wege zu Horaz. Hrsg. von H. Oppermann. Wege der Forschung 99. Darmstadt 1972. 14-36.

${ }^{11}$ Ez utóbbi kérdésnek legszélsőségesebb megítélése: E. Lefèvre: Horaz, Dichter im augusteischen Rom. München 1993. 265-273.
} 
okoskodás alapján - a gens Iulia nemzetségi istenei közé tartozott. ${ }^{12}$ Octavianus színre lépésétől kezdve hangsúlyozta Apollóhoz fúződő szoros kapcsolatát; amit Iulius Caesarnak Venus, számára azt jelentette Apollo. Egy valószínúleg 42-ben rendezett, a „tizenkét isten lakomája”-ként elhíresült jelmezes mulatságon Apollónak öltözve vett részt, ${ }^{13}$ a polgárháborúk idején propagandagépezete előszeretettel emlegette apollói vonásait Antonius dionysosi egyéniségével szemben. A jelek szerint harcaiban is Apollót tartotta védóistenének. Csak ezzel magyarázható, hogy a palatinusi Apollo-templom építésére, melyet 28-ban avattak fel, még 36-ban, a Sextus Pompeius elleni háború idején tett fogadalmat. Azt, hogy ezt a templomot magánbirtokán, in privato solo építtette fel, valószínúleg jelképes aktusnak is szánta, s azzal, hogy ide szállíttatta át a Sybilla-könyveket, szintén az istenhez fúződő szoros kapcsolatát szándékozott hangsúlyozni. Apollo és vele együtt kultusza jelentőségének és tekintélyének megnövekedésében azonban még ennél is nagyobb szerepet játszott az, hogy Aktion (Actium) mellett történetesen egy Apollo-szentély állt, az Apollón Aktiosé. Erre a véletlen egybeesésre alapozva született meg azután az „actiumi csoda”, melynek propagálásában Vergiliusnak és Propertiusnak oroszlánrésze volt, hogy tudnillik Apollo személyesen és tevőlegesen vett részt Octavianus oldalán az ütközetben. ${ }^{14}$ Ezt a véletlen kínálta lehetőséget azután Augustus messzemenően kiaknázta: a csata színhelyén fényes Apollo-templomot építtetett, és Apollo tiszteletére megalapította az actiumi játékokat. Nemzetségének istene actiumi beavatkozásával immár Róma megmentố istenévé lépett eló, úgyhogy méltán válhatott vetélytársává az addig ezt a funkciót elsődlegesen ellátó capitoliumi Iuppiternek.

A palatinusi Apollo-templomot több leírás is megörökítette. Oromzatán a kocsiját hajtó Napisten volt látható; a homlokzat felóli porticus oszlopai között - ahol a kardalt is elóadták - a Danaidák szobrai sorakoztak; bejárati ajtajának két szárnyát elefántcsont dombormúvek díszítették: az egyik Niobé gyermekeinek megölését, a másik a gallok Delphoiból való elúzését ábrázolta. A templom belsejében Apollo, Diana és Létó szobra állt, szokásos attributumaikkal. ${ }^{15}$ Ezen ábrázolások mindegyikének megvolt az Octavianus személyéhez kapcsolódó szimbolikus jelentése (az impietas megbosszulása, az igazságszolgáltatás). ${ }^{16}$ Éppen ezért több, mint meglepő, hogy a Carmen saeculare az Apollo-templom szoborcsoportjával és dombormúveivel, a programjuk mögött meghúzódó elképzelésekkel - kivéve a Napistent - még csak érintkezési pontot sem mutat. Ezt még különösebbé teszi az a körülmény, hogy a

12 Veiovist Bovillae-ben Apollóval hozták kapcsolatba, aki egy 2. századi felirat tanúsága szerint a Iuliusok nemzetségi istenének számított: G. Radke: Die Götter Altitaliens. Münster 1965. 309-310. F. Altheim: Römische Religionsgeschichte. II. Baden-Baden 1953. 208-209.

${ }^{13}$ Suetonius, Augustus 70., J. Gagé: Apollon romain. Essai sur le culte d'Apollon et le developpement de „ritus Graecus” à Rome des origines à Auguste. Paris 1955. 485-488.

${ }^{14}$ J. Gagé: Apollon romain... 499-507. Vergilius, Aen. 8, 704-706., Propertius, IV. 6. 25-56.

${ }^{15}$ Suetonius, Augustus 29., Cassius Dio, 49, 15. 5., Propertius 2, 31, Plinius, NH 36, 24. 25. 32.

${ }^{16}$ J. H. W. G. Liebeschuetz: Continuity and Change in Roman Religion. Oxford 1979. 82-85. E. Lefèvre: Das Bild-Programm des Apollo-Tempels auf dem Palatin. Xenia 24. Konstanz 1989. 
Carm. IV. 6.-ot, a Carmen saeculare párját Horatius éppenhogy a Danaidákkal kezdi (Dive, quem proles Niobea magnae vindicem linguae...sensit, 1-3.), s a carmen központi magját alkotó Achilleus-történet (9-24.) és a bejárati ajtó dombormúvének Niobé-jelenete mondanivalójukat tekintve szintén közeli rokonai egymásnak. Ez a diszkrepancia óhatatlanul fölveti azt a kérdést, hogy valójában melyik Apollo és Diana az, akit Horatius ilyen mértékben kiemel, vagyis a Carmen saeculare e két istenalakjának melyek a leghangsúlyosabb vonásai.

A carmen első két sora: „Phoebe, nemorumque potens Diana, / lucidum caeli decus" Dianát illetôen egyértelmú: Diana a ligetek úrnóje, s egyben azonos a Holddal. Később, a 9. strófában a ligetekkel való kapcsolata el is marad: itt a kar már csak „siderum regina, Luna bicornis”-ként szólítja meg. Nem ennyire egyértelmú viszont — ezért vitákra is adott alkalmat - Apollo, Phoebus és a Nap (Sol) egymáshoz való viszonya. A 9. strófa Apollót és Dianát említi együtt:

$$
\begin{aligned}
& \text { supplices audi pueros Apollo, } \\
& \text { siderum regina bicornis audi } \\
& \text { Luna puellas. (34-36.), }
\end{aligned}
$$

a második nagy egység harmadik tiászában viszont Diana párja már nem Apollo, hanem Phoebus:

$$
\begin{aligned}
& \text { augur et fulgente decorus arcu } \\
& \text { Phoebus acceptusque novem Camenis (61-62.), }
\end{aligned}
$$

és a záróstrófában a két kar szintén Dianatól és Phoebustól köszön el (73-76). A carmenben tehát Apollo és Phoebus között sem tevékenységi körüket, sem attributumaikat illetôen nincs különbség, akár felcserélhetők is volnának egymással.

A kortárs költő́i nyelvben - Vergiliusnál, ${ }^{17}$ Propertiusnál,${ }^{18}$ de magánál Horatiusnál ${ }^{19}$ is - görög hatásra Phoebus korábban is előfordul metonímikusan „Nap” jelentésben, s Apollo és Phoebus lényegi azonossága ugyanígy magától értetődőnek számít. ${ }^{20}$ De nem csak a költői nyelv tett egyenlőségjelet Apollo, Phoebus és a Nap

17 ingens (lumen) quod torva solum sub fronte latebat / Argolici clipei aut Phoebeae lampadis instar (Aen. 3, 636-37) ; ni roseus fessos iam gurgite Phoebus Hibero / tinget equos noctemque die labente reducat $(11,913-914)$

18 non tua deprenso damnata est forma veneno / testis eris puras, Phoebe, videre manus (2, 32, 27-28); tu quoque, qui aestivos spatiosus exigis ignes, / Phoebe, moraturae contrahe lucis iter (3, 20, 11-12)

${ }^{19}$ dum rediens fugat astra Phoebus (Carm. 3, 21, 24)

${ }^{20}$ Iamque aderat Phoebo ante alios dilectus Iapíx/ Iasides, acri quondam cui captus amore/ ipse suas artis, sua munera laetus Apollo/ augurium citharamque dabat celerisque sagittas (Aen. 12, 391-394). Propertius esetében a legismertebb példa erre a 4, 6., ahol a két név szabadon váltakozik egymással: Apollo: 11. 69., Phoebus: 15. 27, 57. 67. 76. 
között. Az istenvilág allegorikus értelmezése során a sztoikusok Apollót a Nappal, Dianát a Holddal azonosították. Az istenpárnak ez a fajta értelmezése a Kr. e. I. században természetesen jól ismert volt abban a Rómában, ahol a magasabb múveltséget célul kitûző képzéshez szinte kötelezően hozzátartozott egy görögországi tanulmányút, melynek egyik célja a filozófiai ismeretek elmélyítése volt. Cicero $D e$ natura deorumában a sztoikus Balbus például a következóképpen nyilatkozik az isteni testvérpárról: „Iam Apollinis nomen est Graecum, quem Solem esse volunt. Dianam et Lunam eandem esse putant, cum Sol dictus sit, vel quia solus ex omnibus siderubus est tantus vel quia, cum est exortus, obscuratis omnibus solus apparet, Luna a lucendo nominata sit." 21 Tekintettel azonban arra, hogy a Carmen saeculare egy államilag rendezett ünnep központilag megrendelt, alkalmi költeménye volt, sem a költôii nyelv, sem a sztoikus filozófia kínálta párhuzamok nem lehetnek feltétlenül mérvadóak Phoebus és Sol egymáshoz való viszonyát illetően, mert bizonyos, hogy Horatiusnak ez esetben nem kis mértékben alkalmazkodnia kellett a római vallás tényleges gyakorlatához és az ünnep rítusához, a kultuszban pedig Apollo és a Nap még Augustus korában is határozottan elkülönült egymástól. A primaportai dombormúvön a Nap Apollo mellett önálló istenként jelenik meg; hasonlóképpen a Napisten szobra a palatinusi Apollo-templom oromzatán egyszerre hangsúlyozza a Nap és Apollo szoros kapcsoltatát, ugyanakkor viszonylagos önállóságát. ${ }^{22}$ Mindez azonban a Kr e. 28. körüli állapotokat tükrözi. A numizmatikai és kisplasztikai emlékek tanúsága szerint viszont éppen a százados játékoktól kezdve mutatható ki az augustusi valláspolitikai formálói részéról az a törekvés, hogy Phoebusból olyan istent alkossanak, aki egyesíti magában Apollo és a Napisten vonásait, s aki természetesen a princeps személyével is kapcsolatba hozhatóo ${ }^{23}$. Ennek talán elsó irodalmi emléke éppen az erre az alkalomra szerkesztett pseudo-Sibyllinum, mely a carmenhez hasonlóan egynek veszi Apollót, Phoebust és a Napot: кaì Фоĩßos 'A $\pi$ ó $\lambda$ ov, /

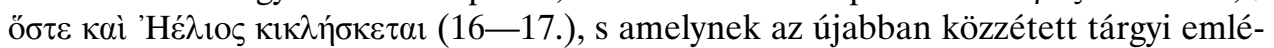
kek ismeretében Apollo római történetét illetően az eddiginél nagyobb jelentőséget kell tulajdonítanunk. De mindettól eltekintve, a kardal szerkezete is alátámasztja Phoebus és Sol azonosságát, hiszen ha a carmen Sol-ját külön, önálló istennek vennénk, ez volna a költemény egyetlen strófája, mely megbontaná annak triadikus szerkezetét. ${ }^{24}$ Minden bizonnyal Porphyrionak volt tehát igaza, aki a lucidum caeli decus-hoz a következô magyarázatot fúzte: Hoc ad ambos refertur, ad Phoebum, quia idem Sol est, et Dianam, quia eadem Luna est. A Naphoz szóló, sokat vitatott strófa:

${ }^{21}$ Cicero: De natura deorum II. 68.

22 J. E. Fontenrose: Apollo and the Sun-God in Ovid. AJPh 61 (1940) 429-444. F. Altheim tagadta Apollo és a Sol azonosságát: i. m. II. 242-246.

${ }^{23}$ E. Simon: Kunst und Leben im Rom um die Zeitwende. München 1986. 21., 31., 54. D. Mannsperger: Apollo gegen Dionysos. Gymnasium 80 (1973) 381-404.

${ }^{24}$ E. Fraenkel: i. m. 370-371., míg G. Williams: Tradition and Originality in Roman Poetry. Oxford 1968. 59. teljesen alaptalanul különválasztja a strófát, mintha önálló szintaktikai egység volna. 


\begin{abstract}
Alme Sol, curru nitido diem qui promis et celas, aliusque et idem nasceris, possis nihil urbe Roma visere maius $(9-12)$
\end{abstract}

teljesen helyénvaló tehát a Dianát és Apollót, mint a Holdat és a Napot szólító első triász záróstrófájaként. Horatius ilyenformán a carmenben Apollónak és Dianának elsősorban a Nappal és a Holddal való kapcsolatát, vagyis kozmikus vonásaikat hangsúlyozza. ${ }^{25} \mathrm{~S}$ ezen a ponton fölmerül a miért kérdése. Az a magyarázat, hogy a kardal szerint Apollo és Diana mint kozmikus istenek őrködnek Róma fölött, ${ }^{26}$ látszólag tetszetôs ugyan, de ebben a formában értelmezhetetlen: ilyen szerepe ugyanis nemcsak a kultikus gyakorlatban nem volt egyiküknek sem, hanem ilyesmit vagy ehhez hasonlót az irodalmi források sem tulajdonítanak nekik.

Az idézett strófa szerint a Nap aliusque et idem nascitur. Ezt természetesen értelmezhetjük úgy is, mint költői kifejezését annak, hogy az égitest naponta lenyugszik és felkel, értelmezhetjük azonban a Nap naponként változó csillagászati helyzete költôi körülírásának is: a Nap ugyanis felkelésekor az előző naphoz viszonyítva az ekliptikának mindig másik fokán jelenik meg, visszatérésekor tehát valóban ugyanaz is és más is, mert mindig új konstellációba kerül. Ha így fogjuk fel — és maga az alkalom, a „korszakváltás” is ezt sugallja —, a carmen a két égitestnek mindenekelőtt az idôvel való kapcsolatát hangsúlyozza. Ezt az értelmezést az is alátámasztani látszik, hogy az időtényezô a carmennek egyébként is a legfôbb rendezô elvei közé tartozik: Horatius mindvégig szisztematikusan törekedett arra, hogy egyszerre villantsa fel költeményében a jelent, a múltat és a jövőt. Ez a törekvése hol kisebb, hol nagyobb egységeken belül nyilvánul meg, de mindvégig érzékelhetô. Az idő hármassága már az invokációban adva van: o colendi semper et culti, date, quae precamur (2-3.); Eileithyiának segítenie kell a még világra nem jöttek megszületését, hogy száztíz év múlva is megrendezhessék a ludi saecularest (13-24.); a Sorsistennőktől a kar azt kívánja, hogy bona iam peractis iungite fata (27-28.). A múlt, a jelen és a jövő együttes megjelenítése a második nagy szerkezeti egységben egyenesen a triászok szintjén érvényesül, amelyekben Aeneas menekülése és a városalapítás a múltat, Augustus uralma a jelent, Apollo pedig, aki alterum in lustrum meliusque semper prorogat aevum (72-73.), a jövôt képviseli. Ezen túlmenően azonban a carmennek van még egy olyan eleme, mely amellett szól, hogy Apollónak és Dianának elsősorban a Nappal és a Holddal való kapcsolatán van a hangsúly: a szerkezete. Mint ahogy a rituálét uraló hármas és kilences szám alapvetôen befolyásolta a kardal tago-

${ }^{25}$ E. Fraenkel: i. m. 373: „In other words, Apollo is here conceived not so much as Apollo Palatinus, but rather as a universal or, as some of our contemporaries would probably prefer to say, a cosmic power”.; G. Pasquali: Orazio lirico... a cura di La Penna. Firenze 1964. 736. ugyanígy.

26 „Sie walten am Himmel als Hüter des Reichs”. E. Lefèvre: Horaz... 268. 
lását, ugyanúgy valószínúleg az sem véletlen, hogy a költemény $2 \times 9=\mathbf{1 8}+1=\mathbf{1 9}$ strófából áll. Mind a 18, mind a 19 fontos szerepet játszik ugyanis a Nap és a Hold egymáshoz való viszonyában: az elsô az úgynevezett Saros-ciklus, a második a Metón-ciklus éveinek a száma.

A Saros-ciklusnak a hold- és a napfogyatkozások egymásutánjának meghatározása szempontjából van jelentősége. Mint közismert, a hold-, illetve a napfogyatkozásokat az okozza, hogy vagy a Föld kerül átmenetileg részben vagy teljesen a Hold árnyékába (= napfogyatkozás), vagy a Hold a Föld árnyékába (= holdfogyatkozás). Ez a helyzet azért állhat elő, mert a Hold keringési síkja eltér a Földétől, következésképp a holdpálya két ponton metszi az ekliptikát: ezek az úgynevezett csomópontok. Hold- vagy napfogyatkozás akkor következik be, ha a Hold teliholdkor vagy újholdkor, vagyis a Nappal való szembenállás (oppozíció) vagy együttállás (coniunctio) idején kerül valamelyik csomópontba. Ezek a csomópontok nem állandóak, hanem vándorolnak az ekliptikán:, évente átlag 20 fokkal mozdulnak el regresszíve, vagyis a zodiakus-csillagképek sorrendjével ellentétes irányban, s ilyenformán $360: 20=18$ év kell ahhoz, hogy az ekliptikának ugyanarra a pontjára érjenek viszsza, vagyis hogy egy teljes kört megtegyenek. Ennek az a következménye, hogy a hold- és a napfogyatkozások 18 éves cikluson belül megközelítőleg ugyanabban a ritmusban és sorrendben követik egymást. ${ }^{27}$

A Metón-ciklusnak a holdhónapok és a napév közötti összhang megteremtésében, a naptárak készítésében volt nagy jelentôsége. A luniszoláris naptárak szerkesztői számára a legnagyobb nehézséget kezdettől fogva az okozta, hogy sem az év, sem a holdhónap napjainak száma nem fejezhetô ki egész számok többszöröseként, továbbá az, hogy 12 holdhónap hossza nem egyenlő egy napév hosszával. A tropikus év — amíg a Nap a tavaszponttól a tavaszponthoz ér - 365,24219 napból áll, míg egy szinodikus holdhónap - az újholdtól újholdig, vagy holdtöltétốl holdtöltéig eltelt idó - 29,53055 nap. A tizenkét holdhónap napjainak száma tehát $29,53055 \times 12=$ =354,3966, ami 10,8753 nappal kevesebb a tropikus év hosszánál. A holdhónapok és a napév közötti hozzávetőleges összhang megteremtése tehát csak úgy lehetséges, hogy meghatározott idóközönként napokat vagy hónapokat iktatuk be. A görög asztronómusok körülbelül kétszáz évig kísérleteztek a probléma megodásával elóbb négyéves (tetraeteris), majd nyolcéves (octoeteris) ciklusokkal próbálkoztak, ${ }^{28}$ míg végül az Aristophanés ${ }^{29}$ által nem éppen rokonszenvesnek ábrázolt athéni csillagásznak, Metónnak sikerült megoldani a problémát. Metón egy 235 holdhónapból álló ciklust vett alapul, ami 6940 nap $(29,53055 \times 235=6936,6792)$, vagyis 19,0010 év. A 235 holdhónapból 125-öt teljes, 110-et hiányos hónapnak vett; a teljes hónapok

27 O. Neugebauer: Egzakt tudományok az ókorban. Budapest 1986. 153-155.; Mahler E.: Az ókori nap- és holdfogyatkozásokról. Természettudományi Közlöny 33 (1901) 371-383.; H. Bukor-R. Bukor: Csillagászat. Springer Hungarica 1996. 53.

${ }_{28}$ Részletes ismertetése az ókorból: Geminos: Eisagógé VIII.

${ }^{29}$ Madarak 992-1020. 
30, a hiányosak 29 naposak voltak. Erre az eredményre úgy jutott, hogy mivel 235 teljes hónap $235 \times 30=7050$ nap lett volna, 235 holdhónap viszont csak 6940 napból áll, a kettô közötti különbséggel, ami $7050-6940=110$, elosztotta a 6940 napot. A $6940: 110=63,0909$-cel, a különbség kiegyenlítése végett tehát minden 63. napot elhagyott. ${ }^{30} \mathrm{Az}$ évek elvben 12 harminc napos hónapból álltak, mivel azonban minden 63. nap kiesett, a gyakorlatban 30 és 29 napos hónapok váltották meghatározott rend szerint egymást: pl. 30, 30, 29, 30, 29. Az így összeállt 12 hónapos évet azután úgy hozta összhangba a napévvel, hogy a 2., 5., 8., 10., 13., 16., 18. évben egy plusz hónapot iktatott be; ezek az intercalaris évek tehát 13 hónaposak voltak. A 19 éves ciklusnak „nagy év”, vagy „Metón-év” volt a neve (

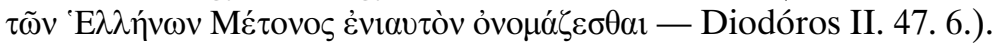

Metón 432. június 27-én tette közzé számításait és ciklusát, s ettól kezdve a legtöbb görög naptár ezt, a fent vázolt módszert alkalmazta az évek és a hónapok felosztásában. Diodóros Siculus szerint — aki Horatius kortársa volt — megbízható-

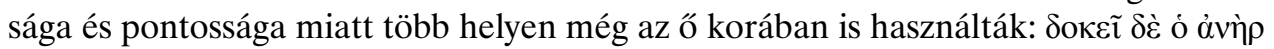
ỡ்

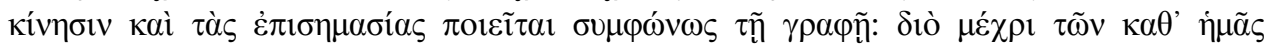

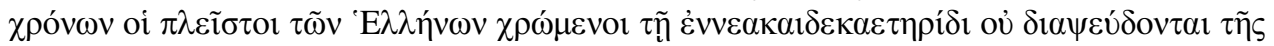
$\dot{\alpha} \lambda \eta \theta \varepsilon i ́ a \varsigma$ (XII. 36. 3.). Noha a római naptár egészen Iulius Caesar naptárreformjáig más elvek szerint múködött, Metón neve és a neki tulajdonított ciklus Rómában sem volt ismeretlen: Cicero egyik Atticushoz írt levelében mint közismert dologra hivatkozik rá: „, Aut quando iste Metonis annus veniet?” (Ad Att. 12, 3, 2, 5.), Plinius a NHban mint egyik forrását említi (I. 18.). Több jel mutat egyébként is arra, hogy a Kr. e. I. századi római értelmiség körében meglehetôsen élénk lehetett a csillagászat iránti érdeklődés: ennek jeleként foghatjuk fel többek között Cicero és Germanicus Aratos-fordítását, de hasonló mentalitás tükröződik közvetve az Aeneis Iopasának énekében is:

canit errantem lunam solisque labores...

quid tantum Oceano properent se tinguere soles

hiberni, vel quae tardis mora noctibus obstet. (I. 742. és 745-746.)

Iulius Casar naptárreformja közelében ebben semmi meglepó nincs.

A Metón-ciklus bevonása vizsgálatunkba azonban nemcsak a Carmen saeculare strófáinak számára adhat magyarázatot, hanem arra a mindmáig tisztázatlan kérdésre is, hogy Augustus a ludi saecularest miért 17-ben és nem 16-ban rendezte meg. A római hagyományban ugyanis a „századéves játékok”-ra vontkozóan kétféle hagyomány létezett. Az egyik 449-tól kezdve 100 éves saeculumokkal számolt és 449-, 349-,

${ }^{30}$ A. E. Samuel: Greek and Roman Chronology. Handbuch der Altertumswissenschaft I. 7. München 1972. 42-51. 
(249?)-, 149-ben megrendezett ünnepekrôl tudott. Augustus azonban nem ezt, hanem a quindecemvirek testületének hagyományait és számítási módszerét vette alapul, amely egy saeculumot 110 évesnek véve, 456-tól kezdődően ilyen időközönként tételezte fel a ludi saeculares megrendezését: azaz 456-, 346-, 236-, 126-ban, és ezután logikusan 16-nak kellett volna következnie. ${ }^{31}$

Abban, hogy az ünnepet egy évvel előbbre hozták, bizonyára szerepet játszott a 17-ben feltúnt sidus Iulium, ezenkívül azonban valószínúleg az is, hogy a Kr. e. 17. egy új metóni „nagy év” volt. Ez akár az egyházi naptárak készítésénél használt, úgynevezett Gregorián-epaktum segítségével is kiszámítható. E szerint a „Hold korát” úgy állapíthatjuk meg, hogy a mindenkori évszámhoz hozzáadunk 1-et, majd az így kapott összeget elosztjuk 19-cel: a maradék azt mutatja meg, hogy az utolsó újhold napjától hány nap telt el az új év elsô napjáig. Ha a maradék 0 , az annyit jelent, hogy az újhold és az újév napja egybeesik, vagyis újabb 19 éves ciklus kezdődik. Mivel Dionysius nem számolt nulladik évvel, a Kr. e. évek esetében az évek számát 1-gyel meg kell növelnünk, Kr. e. 17 tehát csillagászatilag 18-nak számít. A Gregorián epaktum számítási módszere alapján: $18+1=19,19: 19=1,00$, vagyis 17-ben (csillagászatilag 18-ban) valóban egy új ciklus kezdődött. Magát az ünnepet nyilván azért tették május végére - június elejére, mert a római felfogás szerint május az idősek, június az ifjak hónapja volt.

Diodóros Metónt asztrológusnak nevezi, ${ }^{32} \mathrm{~s}$ valóban, a Kr. e. I. században az asztronómia és az asztrológia már szorosan összetartozó fogalmak még a princeps környezetében is, ennek ellenére a carmenben az asztrológia csak nagyon burkoltan van jelen, legfeljebb abban nyilvánul meg, hogy az elsố nagy szerkezeti egységben elsősorban a termékenységről, a másodikban fớként Róma hatalmáról és dicsőségéról esik szó: az asztrológiában az elóbbihez óhatatlanul a Hold, az utóbbihoz a Nap képzete társul. Az asztrológia azonban majd csak a fiatalabb kortárs, Propertius „római elégiáiban” válik jelentôs tényezôvé.

${ }^{31}$ M. P. Nilsson: i. m. 1699-1700. c.

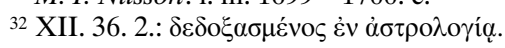

